\title{
Brochothrix, a New Genus Tentatively Placed in the Family Lactobacillaceae
}

\author{
P. H. A. SNEATH AND DOROTHY JONES \\ Department of Microbiology, The University, Leicester, England
}

\begin{abstract}
Microbacterium thermosphactum McLean and Sulzbacher differs to such an extent from the type species of Microbacterium, $M$. lacticum Orla-Jensen, that it cannot be retained in this genus. Recent studies have shown that $M$. thermosphactum strains form a distinct taxon worthy of genus status. A new genus, Brochothrix, is established for the species B. thermosphacta (McLean and Sulzbacher) comb. nov. This genus is tentatively placed in the family Lactobacillaceae. B. thermosphacta is the type species of the genus, and ATCC 11509 is designated to be the type strain of $B$. thermosphacta.
\end{abstract}

The species Microbacterium thermosphactum was described by McLean and Sulzbacher (15) to accommodate some gram-positive, nonsporing, catalase-positive, fermentative rods isolated from pork sausage meat. The taxon is well characterized $(1,2,4-6,9,15,20,21,25$, 27 ). The only notable discrepancy between the observations of later workers and those of McLean and Sulzbacher (15) concerns $\mathrm{CO}_{2}$ production during fermentation of carbohydrates. McLean and Sulzbacher noted production of $\mathrm{CO}_{2}$, but this has not been confirmed by subsequent studies $(2,4,5,7,8,11,25)$.

Since the first description of $M$. thermosphactum (15), bacteria of this type have been isolated with increasing frequency from a whole range of meat and meat products, especially prepacked meat $(1,2,9,10,17,24,25,27)$. However, the taxonomic position of the taxon has been, and still is, unsatisfactory (20). McLean and Sulzbacher (15) admitted that in the majority of characteristics the unknown bacterium studied by them appeared to be closely related to the genus Lactobacillus but, because it was catalase positive, they stated that "it certainly falls into the genus Microbacterium." Subsequent workers have drawn attention to the marked difference between $M$. thermosphactum and the type species of the genus, $M$. lacticum (16), in morphology $(5,11)$, enzymology, and protein profiles $(4,19)$ and in deoxyribonucleic acid (DNA) base-ratio values (4). In addition, numerical taxonomy studies that have included representatives of the genus $M i$ crobacterium, corynebacteria, and lactic acid bacteria have all shown that $M$. thermosphactum strains group as a distinct cluster (with an intragroup similarity of greater than $85 \%$ ) quite separate from $M$. lacticum $(7,8,11$; B. J. Wilkinson, Ph.D. thesis, Univ. of Leicester, Leicester, England, 1973).
In all of the studies, the closest associates of the $M$. thermosphactum group were the taxa representing the genera Listeria and Lactobacillus, but the relationship is not close enough to indicate that $M$. thermosphactum strains could be accommodated as a species in either of these genera.

On the basis of all of this information, we consider that the bacteria now referred to as $M$. thermosphactum should be reclassified in a new genus, for which we propose the name Brochothrix (brochos Gr. n. loop; thrix Gr. n. thread; M.L. fem. n. Brochothrix loop thread), composed of one species, $B$. thermosphacta (McLean and Sulzbacher) comb. nov. We designate strain SW26 (= ATCC $11509=$ NCIB 10018), one of the original isolates of McLean and Sulzbacher (15), to be the type strain of $B$. thermosphacta.

\section{Description of the New Genus Brochothrix}

The salient characters of this genus, based on the literature descriptions of Microbacterium thermosphactum Orla-Jensen (1, 2, 4-10, $15,20,22,25)$ and our own observations, are as follows. Gram stains of exponential-phase cultures show rods occurring singly, in short chains, or in long, kinked, filamentous-like chains which bend and loop to give characteristic knotted masses. In stationary-phase cultures, the rods give rise to coccoid forms which, on subculture onto a suitable medium, develop into rod forms (5). The length of the rod is from 1 to $2 \mu \mathrm{m}$; the diameter is from 0.6 to $0.75 \mu \mathrm{m}$. Gram positive, but some cells lose the ability to retain the Gram stain. Nonmotile. No endospores are produced. Nonhemolytic. Optimum growth temperature, 20 to $22 \mathrm{C}$. Growth occurs at 1 and $30 \mathrm{C}$ but not usually at 35 to $37 \mathrm{C}$. Not heat resistant. Facultative anaerobes. Glucose metabolism is fermentative. Acid without gas 
usually produced from arabinose, cellobiose, dulcitol, glucose, lactose, maltose, mannitol, sucrose, and xylose. Methyl red and VogesProskauer tests are positive, $\mathrm{H}_{2} \mathrm{~S}$ and indole are not produced, nitrate is rarely reduced $(2,9)$, gelatin is not liquefied, and exogenous urea and citrate are not utilized. Catalase and cytochromes are present, but their production depends on the growth medium and temperature of incubation. Both are present in measurable amounts when the bacteria are grown on APT (Difco) medium at $20 \mathrm{C}$, but weaker or negative reactions are obtained at the same temperature on HIA (Difco) medium. Negative results are frequently obtained if the bacteria are grown on either medium and incubated at $30 \mathrm{C}$ (5).

Cell walls contain meso-diaminopimelic acid, glutamic acid, and alanine but not arabinose or galactose $(21,22)$. The guanine plus cytosine content of the DNA determined by estimation of melting point is $36 \mathrm{~mol} \%$ (4).

The type species is $B$. thermosphacta (McLean and Sulzbacher) comb. nov.

\section{Description of $B$. thermosphacta}

This description is based on studies of the type strain SW26 (= ATCC $11509=$ NCIB 10018) $(2,4,5,15,21,23)$ and our own observations.

Surface colonies on nutrient agar ( 1 to 2 days) are circular, $0.75 \mathrm{~mm}$ in diameter, convex with entire margin, and not pigmented; the surface is glossy. In older cultures, the edge breaks up and the center of the colony becomes raised to give a "fried-egg" appearance.

Cultures may contain colonies of both types at one time (2). Colony size is markedly increased if glucose is included in the medium. Gram stains of exponential- and stationaryphase cultures show the growth cycle described for the genus (5). Optimum growth temperature, 20 to $22 \mathrm{C}$. Growth at $1 \mathrm{C}$ but not at $37 \mathrm{C}$. Does not survive heating at $63 \mathrm{C}$ for $5 \mathrm{~min}$. Facultatively anaerobic. Glucose metabolism is fermentative; lactic acid [mainly $\mathrm{L}(+)$ ], with only small amounts of by-products, is produced. Acid but no gas produced from arabinose, cellobiose, fructose, glucose, glycerol, lactose, maltose, mannitol, mannose, melezitose, rhamnose, salicin, sorbitol, sucrose, and xylose. Weak or delayed (7 days) acid production from adonitol, dulcitol, galactose, inositol, and melibiose. No acid produced from sorbose. Milk is made slightly acid, otherwise unchanged. Methyl red and Vogues-Proskauer positive. $\mathrm{H}_{2} \mathrm{~S}$ and indole not produced, sodium hippurate not hydrolyzed, nitrate not reduced, gelatin not liquefied, casein not digested, and deoxyribonu- clease not produced. Does not hydrolyze tweens 20, 40, 60, and 80. Exogenous urea and citrate not utilized. Enzymes of the tricarboxylic acid cycle almost totally absent (4). Cell walls contain meso-diaminopimelic acid, glutamic acid, and alanine but not arabinose or galactose (21, 22). The major phospholipids are phosphatidylglycerol, bis-phosphatidylglycerol, and phosphatidylethanolamine; the glycolipid fraction contains acetylated glucose and small amounts of a glycosyl diglyceride. The fatty-acid components are predominantly $\mathrm{C}_{15}$ and $\mathrm{C}_{17}$ branchedchain isomers (23). The guanine plus cytosine content of the DNA is $36 \mathrm{~mol} \%$ (4).

\section{Family Relationship of the Genus Brochothrix}

The higher taxonomic affiliation of the genus Brochothrix could be controversial. Most numerical taxonomy studies $(7,11$; Wilkinson, $\mathrm{Ph} . \mathrm{D}$. thesis) indicate a fairly close relationship to the lactic acid bacteria, and this relationship is reinforced by the results of enzyme $(4,14)$ and DNA base-ratio studies (4). The apparent close relationship to Kurthia indicated by the numerical taxonomy study of Davis and Newton (8) was almost certainly due to the choice of tests used in this study.

We consider, in the light of present knowledge $(3,18)$, that the presence of catalase and cytochromes in $B$. thermosphacta is not sufficient reason to exclude it from the family Lactobacillaceae. Although Schleifer (21) was of the opinion that the presence of meso-diaminopimelic acid in the cell wall indicated a closer relationship to the corynebacteria, other studies $(12,13,26)$ have shown that meso-diaminopimelic acid also occurs in the cell walls of certain lactobacilli, and in a later paper Schleifer and Kandler (22) stated that B. thermosphacta is not closely related to the animal corynebacteria because its cell walls do not contain arabinose and galactose. However, Shaw and Stead (23) have reported that the lipid composition of $B$. thermosphacta is incompatible with that of the Lactobacillaceae.

We do not yet have sufficient knowledge to judge the weight that should be given to these latter findings in the context of the very strong evidence provided by other criteria that $B$. thermosphacta should be classified in the family Lactobacillaceae, and we suggest, therefore, that Brochothrix be placed in this family for the present.

\section{REPRINT REQUESTS}

Address reprint requests to: Dorothy Jones, MRC Microbial Systematics Unit, Adrian Building, University Road, Leicester LE1 7RH, England. 


\section{LITERATURE CITED}

1. Ayres, J. C. 1960. Temperature relationships and some other characteristics of the microbial flora developing on refrigerated beef. Food Res. 25:1-18.

2. Barlow, J., and A. G. Kitchell. 1966. A note on the spoilage of prepacked lamb chops by Microbacterium thermosphactum. J. Appl. Bacteriol. 29:185-188.

3. Bryan-Jones, D. G., and R. Whittenbury. 1969. Haematin-dependent oxidative phosphorylation in Streptococcus faecalis. J. Gen. Microbiol. 58:247-260.

4. Collins-Thompson, D. L., T. Sorhaug, L. D. Witter, and Z. J. Ordal. 1972. Taxonomic consideration of Microbacterium lacticum, Microbacterium flavum, and Microbacterium thermosphactum. Int. J. Syst. Bacteriol. 22:65-72.

5. Davidson, C. M., and E. F. Hartree. 1968. Cytochrome as a guide to classifying bacteria: taxonomy of Microbacterium thermosphactum. Nature (London) 220:502-504.

6. Davidson, C. M., P. Mobbs, and J. M. Stubbs. 1968 Some morphological and physiological properties of Microbacterium thermosphactum. J. Appl. Bacteriol. 31:551-559.

7. Davis, G. H. G., L. Fomin, E. Wilson, and K. G. Newton. 1969. Numerical taxonomy of Listeria, streptococci and possibly related bacteria. J. Gen. Microbiol. 57:333-348.

8. Davis, G. H. G., and K. G. Newton. 1969. Numerical taxonomy of some named coryneform bacteria. J. Gen. Microbiol. 56:195-214.

9. Gardner, G. A. 1966. A selective medium for the enumeration of Microbacterium thermosphactum in meat and meat products. J. Appl. Bacteriol. 29:455460 .

10. Gardner, G. A., A. W. Carson, and J. Patton. 1967. Bacteriology of prepacked pork with particular reference to the gas composition within the pack. J. Appl. Bacteriol. 30:321-333.

11. Jones, D. 1975. A numerical taxonomic study of coryneform and related bacteria. J. Gen. Microbiol. 87:5296.

12. Kandler, O. 1967. Taxonomie und technologische Bedeutung der Gattung Lactobacillus Beijerinck. Zentrabl. Bakteriol, Parasitenk. Infektionskr. Hyg. Abt. 1 Suppl. 2:491-507.

13. Kandler, O. 1970. Amino acid sequence of the murein and taxonomy of the genera Lactobacillus, Bifidobacterium, Leuconostoc, and Pediococcus. Int. J. Syst.
Bacteriol. 20:491-507.

14. London, J., and K. Kline. 1973. Aldolase of lactic acid bacteria: a case history in the use of an enzyme as an evolutionary marker. Bacteriol. Rev. 37:453-478.

15. McLean, R. A., and W. L. Sulzbacher. 1953. Microbacterium thermosphactum, spec nov; a nonheat resistant bacterium from fresh pork sausages. J. Bacteriol. 65:428-433.

16. Orla-Jensen, S. 1919. The lactic acid bacteria. A. F. Host \& Son, Copenhagen.

17. Pierson, M. D., D. L. Collins Thompson, and E. J. Ordal. 1970. Microbiological, sensory and pigment changes of aerobically and anaerobically packaged beef. Food Technol. 24:1171-1175.

18. Ritchie, T. W., and H. W. Seeley. 1974. Cytochromes in Streptococcus faecalis var. zymogenes grown in a haematin containing medium. J. Gen. Microbiol. 85:220228.

19. Robinson, K. 1966. Some observations on the taxonomy of the genus Microbacterium. II. Cell wall analysis, gel electrophoresis and serology. J. Appl. Bacteriol. 29:616-624.

20. Rogosa, M., and R. M. Keddie. 1974. Genus Microbacterium Orla-Jensen, p. 628. In R. E. Buchanan and N. E. Gibbons (ed.), Bergey's manual of determinative bacteriology, 8th ed. The Williams \& Wilkins Co., Baltimore.

21. Schleifer, K. H. 1970. Die Mureintypen in der Gattung Microbacterium. Arch. Mikrobiol. 71:271-282.

22. Schleifer, K. H., and O. Kandler. 1972. Peptidoglycan types of bacterial cell walls and their taxonomic implications. Bacteriol. Rev, 36:407-477.

23. Shaw, N., and D. Stead. 1970. A study of the lipid composition of Microbacterium thermosphactum as a guide to its taxonomy. J. Appl. Bacteriol. 33:470-473.

24. Thornley, M. T. 1957. Observations on the microflora of minced chicken meat irradiated with $4 \mathrm{MeV}$ cathode rays. J. Appl. Bacteriol. 20:286-298.

25. Weidemann, J. F., 1965. A note on the microflora of beef muscle stored in nitrogen at $0^{\circ}$. J. Appl. Bacteriol. 28:365-367.

26. Weiss, N., R. Plapp, and O. Kandler. 1967. Die Aminosäuresequenz des DAP haltigen Mureins von $L a c$ tobacillus plantarum und Lactobacillus inulinus. Arch. Mikrobiol. 58:313-323.

27. Wolin, E. F., J. B. Evans, and C. F. Niven. 1957. The microbiology of fresh and irradiated beef. Food Res. 22:682-696. 